\title{
PRZYCHYLNOŚĆ RZEŹNIKA. WIZJA ŁADU STOWARZYSZENIOWEGO EDWARDA ABRAMOWSKIEGO
}

\author{
Andrzej Waśkiewicz \\ Uniwersytet Warszawski
}

\section{/// Abramowski czytany po kryzysie 2008 roku}

Edward Abramowski należy do tych zasłużonych myślicieli, których spotkało niezasłużone zapomnienie. Dopiero równe rocznice - w jego przypadku stulecie śmierci - skłaniają znawców jego myśli, by przypomnieć je współczesnym. Ale zapomnienie może mieć też paradoksalnie dobroczynne skutki dla takiego autora, którego myśl wykracza poza kontekst historyczny, a nie jest przy tym stale aktualna, jak tych nielicznych, którym przyznaje się miano klasyków. Taki autor musi najzwyczajniej poczekać na swoje ponowne odkrycie, a że historycy idei lubują się w wyszukiwaniu prekursorów myśli rewolucyjnych, jego cierpliwość zostanie zapewne kiedyś nagrodzona. Jeśli jeszcze należał do kategorii „intelektualistów totalnych” - myślicieli zaangażowanych społecznie - to do renesansu jego myśli moga się przyczynić bynajmniej nie akademiccy czytelnicy jego pism.

Wydaje się, że w przypadku Abramowskiego, tym „szczęśliwym” wydarzeniem był kryzys ekonomiczny 2008 roku, którego społecznych skutków świat doświadcza do dzisiaj. Zniszczył on wiarę w kapitalizm jako ustrój, który wymaga jedynie korekty, naruszył niemal dogmatyczne przekonanie, że - trawestując popularny slogan z czasów realnego socjalizmu „Kapitalizm - tak, wypaczenia - nie!”. Spowodował wreszcie wysyp mniej lub bardziej antykapitalistycznych teorii, w tym także antykapitalistycznych 
utopii. Pojawiły się one pod szyldem „postwzrostu”, ekonomii współdzielenia, społeczeństwa zerowych kosztów krańcowych i temu podobnych. Upraszczając całą ich złożoność, owe rewolucyjne projekty podzielić można na trzy nurty: ,przedkapitalistyczny”, ,akapitalistyczny” i „postkapitalistyczny"1.

Szczęśliwe społeczeństwa, których wizje przedstawiają, nie znają towarowej wymiany dóbr między ludźmi ani procedury redystrybutywnej, która koryguje jej niekorzystne społecznie skutki. Mechanizmowi wymiany rynkowej odpowiadaja tu odpowiednio reglamentowanie zasobów rzeczy, jakimi zbiorowo i/lub indywidualnie dysponują członkowie społeczeństwa - nikt nie będzie dysponować nadwyżką dóbr, która przekształci w relację nadrzędności wobec innych; odtowarowienie rzeczy poprzez nadanie im statusu darów - ludzie podejmują wymianę darów tylko z tymi, którzy mogą je odwzajemnić, oraz odwartościowanie (w sensie ekonomicznym) rzeczy za sprawa ich powszechnej dostępności - każdą potrzebę materialną człowiek będzie mógł zaspokoić bez popadania w zależność od drugiego.

Nie są to oczywiście myśli zupełnie nowe. Nurt pierwszy można wyśledzić już w największych dziełach Platona, w jego Państwie i Prawach, nurt drugi zapoczątkował Arystoteles swoją koncepcja przyjaźni dla korzyści, a trzeci Francis Bacon w swojej Nowej Atlantydžie, czytanej w kontekście jego nowatorskiej wizji nauki zaprezentowanej w Novum Organum. Za najbardziej dopracowany i jednocześnie najbarwniejszy projekt z nurtu platońskiego uznać można Utopię Thomasa More’a, szczegółową, choć już nie barwną ilustracją nurtu trzeciego będzie z kolei ład technokratyczny naszkicowany przez Claude'a-Henriego Saint-Simona. Edward Abramowski z jego wizja porządku społecznego opartego na dobrowolnych stowarzyszeniach zdaje się natomiast świetnie rozwijać wspomnianą Arystotelesowską ideę przyjaźni.

Ale której przyjaźni? Z pewnością nie tej, która dla Arystotelesa jest równoznaczna $z$ więzią obywatelska, ponieważ opiera się ona na niewolnictwie. To niewolnicy dostarczają obywatelom wszystkich rzeczy potrzebnych do życia biologicznego; ich samych wiąże tylko jedna rzecz wspólna - rzecz polityczna - czyli państwo. Rzec można sarkastycznie, że na taką przyjaźń w XX wieku moga sobie pozwolić jedynie dżentelmeni, którzy żyja z renty ziemskiej albo z zysku, jaki przynosza ich fabryki. Przyjaźń Abramowskiego, nie mogąc być pozbawiona aspektu materialnego, wpi-

\footnotetext{
${ }^{1}$ Piszę o nich w książce Ludzie-rzeczy-ludzie. Rz̨eczo o utopiach, w których ržeczy laczq, a nie dziela (2020, w druku). O nieco wcześniejszych projektach można przeczytać w książce pod redakcją Piotra Żuka Spotkania ₹utopia w XXI wieku (2008).
} 
suje się zatem w inny nurt arystotelesowskiej przyjaźni: przyjaźni gorszego sortu, ze względu na korzyść ${ }^{2}$.

Arystoteles mógł ją traktować jako pewien naddatek do swojej ekonomii, ponieważ za jednostkę zdolną do utrzymania życia biologicznego uważał gospodarstwo domowe. W greckiej polis produkcja miała bowiem charakter prywatny, tak samo jak konsumpcja; wymiana dóbr służyła jedynie urozmaiceniu tej drugiej. Idealni obywatele powinni być samowystarczalni; jeśli już wchodzą ze sobą w wymianę rzeczy, to bynajmniej nie po to, by zaspokajać swoje potrzeby materialne, ale by ćwiczyć się w cnocie hojności. Nie wymieniają towarów, ale dary; ważne jest dla nich dawanie, nie branie. W przyjaźni ze względu na korzyść jest natomiast odwrotnie: zgodnie ze społecznymi normami dar trzeba odwzajemnić; przyjá́n ta ma więc swoją ekonomię i rządzące nią reguły, bliskie, ale nie tożsame ze sprawiedliwością. Rzec można, że taki związek opiera się bardziej na rozumie niż emocjach.

\section{/// Socjalizm, czyli państwowa niewola}

Abramowski jest nie tylko wizjonerem ładu opartego na stowarzyszeniach; w nie mniejszym stopniu jest krytykiem wszelkich związków między ludźmi opartych na przymusie, a więc także państwa. Dlatego też odrzuca socjalizm w jego etatystycznej wersji. Zniesienie własności prywatnej nie uwolni człowieka od przymusu, który tylko zmieni swoje oblicze - teraz państwo będzie wymuszać świadczenie pracy na rzecz bezklasowego społeczeństwa. Socjalizm jest dla Abramowskiego projektem całkowitej kontroli nad światem rzeczy, a zatem i ludzi, którzy tych rzeczy potrzebują ${ }^{3}$. Ludzie powinni się bowiem związać ze sobą za pośrednictwem rzeczy jedynie z własnej woli, nawet jeśli dzieje się to pod presją materialnych potrzeb. Socjalizm jest ideą co prawda emancypacyjną, skoro dąży do demokratyzacji społeczeństwa, ale również emancypacji przeciwną, ponieważ demokratyzację społeczeństwa sprowadza do demokratyzacji państwa, ale

\footnotetext{
${ }^{2}$ Nie znaczy to, że Abramowski podąża śladami Arystotelesa, jego wizja natury ludzkiej jest bowiem bardziej optymistyczna niż greckiego filozofa, który zwraca uwagę na niestabilność takiego związku. O tej przyjaźni, ze szczególnym uwzględnieniem rządzących nią zasad, piszę w artykule Pr₹yją́n dla korzyści, ale też z korzyścia dla spoteczeństwa (Waśkiewicz 2017).

${ }^{3}$ Tuż przed wybuchem II wojny światowej Karl Mannheim napisze: „Współzawodnictwo z państwami totalitarnymi zmusza państwa demokratyczne do posłużenia się choć niektórymi z ich metod. To znów ukazuje nam kwestię pod innym kątem; współczesne, na wpół totalitarne demokracje, mają tę samą strukturę podstawowa [kapitalistyczna - A.W.], co ustroje całkowicie totalitarne" (Mannheim 1974: 500).
} 
zachowuje jego aparat przemocy ${ }^{4}$. Można powiedzieć, że anarchizm Abramowskiego wyrasta z jego krytyki marksizmu, a jego syndykalizm - choć sam tego nigdzie nie deklaruje - z rzeczonej Arystotelesowskiej idei przyjaźni ${ }^{5}$.

Co warte podkreślenia, krytyka Abramowskiego nie dotyczy tylko marksizmu i socjalizmu państwowego, ale też socjalizmu w wersji rewizjonistycznej, odrzucającego rewolucję. Nie ma dla niego więcej sympatii, skoro i on zakłada przejęcie państwa, a następnie użycie go do przeprowadzenia bezkrwawej rewolucji socjalnej. Ta rewolucja, podkreśla Abramowski, musi się przecież dokonać także wbrew woli większości, którą stanowią chłopi i drobnomieszczaństwo, nie podzielające bynajmniej celów walki proletariatu. „Prawodawstwo bezpośrednie, ludowe” nie powinno być zdominowane przez proletariat, a to jest zupełnie możliwe, ponieważ dzięki organizacji w wielkomiejskich ośrodkach przemysłowych przedstawiciele robotników mogą opanować parlament. I nawet jeśli władza robotników w demokratycznym państwie nie będzie dyktatura, to samo państwo, rozrośnięte i wszechobecne, będzie nie mniej uciążliwe od państwa socjalistycznego.

Nie ma to wielkiego znaczenia, że przymus ten będzie usankcjonowany wolą większości, ani też to, że wskutek rozwoju przemysłu dzisiejsza mniejszość jutro może stać się większościa (por. Abramowski 1986: 168). W demokracji „prawdziwie wolnościowej”

sprawa swobodnego rozwoju pewnej odmiennej grupy lub pewnego prądu nie powinna być warunkowana zdobyciem wiekszości. Nie chodzi już o to, czy zdobycie takie jest możliwe, czy nie, lecz że jest ono prz̨ecinwolnościowe, że jest zdobyciem wolności dla siebie kosztem wolności innych, podstawieniem jednej normy przymusowej na miejsce drugiej. Metoda taka, postawiona przed sądem sprawy wyzwolenia człowieka, staje się zupełnym absurdem i powtórzeniem tego samego, co rozgrywało się we wszystkich tyraniach i uciskach [...] (Abramowski 1965: 291).

\footnotetext{
${ }^{4}$ Socjaliści i komuniści zarzucali z kolei spółdzielcom, że ze swą drobnomieszczańską świadomością są w istocie organizacją obronną klasy średniej (por. Gide 1937: 141).

${ }^{5}$ Przyjaźni jako emocjonalnej i spontanicznie powstającej relacji między ludźmi poświęca Abramowski duży fragment w Metafízye doświadczalnej (1980). Co jednak charakterystyczne, nawet jej nie przywołuje w tym kontekście, trudno więc uznać ją za komplementarną wobec przyjaźni ze względu na korzyść.
} 
Życie polityczne w Europie przygotowującej się do wielkiej wojny dostarcza Abramowskiemu także wielu przykładów poświęcenia „sprawy wyzwolenia człowieka" interesom państw narodowych; przywódcy socjalistyczni pokrętnie przy tym dowodzą zgodności swego postępowania z doktryną (por. tamże: 246-251). W opinii Abramowskiego taka strategia jest szczególnie szkodliwa: tępi emancypacyjne ostrze socjalizmu, zaciera też granice między państwem klasowym i kolektywistycznym. Postępujące upaństwowienie polityki socjalnej, edukacyjnej i kulturalnej musi prowadzić do postrzegania państwa jako instytucji niezbędnej i „naturalnej”, a ostatecznie nawet do zatraty przez ludzkość ,instynktu” samoorganizacji. Ideały wolnościowe, tak indywidualistyczne, jak kolektywistyczne, staja się swoim zaprzeczeniem, jeśli zostaną wcielone przez państwo (por. tamże: 242). „Rewolucja ludowa - konkluduje filozof - wymaga tych właśnie cech moralnych i życiowych, które upaństwowienie zabija" (tamże: 254).

Ale też jest on świadomy, że organizacja życia społecznego, jaką chce wprowadzić socjalizm państwowy, takich cech nie potrzebuje. Scentralizowany system gospodarczy z konieczności wymaga scentralizowanej administracji; warunki produkcji, tak rolnej, jak fabrycznej, wymagaja traktowania ludzi jako siły roboczej podporządkowanej efektywności procesu wytwórczego. Ekonomiczny przymus państwa kapitalistycznego zostaje tu zastąpiony przymusem politycznym, „sztuczną siłą rządu i jego organów wykonawczych" (Abramowski 2009: 43), którą socjalizm państwowy przejmuje po monopolistycznym kapitalizmie.

Wszystko musiałoby być tutaj uregulowane jak w najdoskonalszym mechanizmie i podległe jednakowym powszechnym prawidłom. [...] Jedna tylko władza państwowa, odpowiedzialna za całość gospodarki społecznej, mogłaby decydować w jej zasadniczych sprawach i musiałaby mieć silną rękę, posłusznych obywateli, ażeby jej prawa i najmniejsze rozporządzenia gospodarskie wykonywały sumiennie i ściśle (tamże: 39).

\footnotetext{
${ }^{6}$ Bertrand Russell w znanej książce Drogi do wolności. Socjalizm, anarchižm $i$ syndykalizm tak ujmuje różnicę między stosunkiem wobec państwa trzech tytułowych ruchów: „Ortodoksyjni socjaliści zadowalają się w dziedzinie rządu parlamentarną demokracją, sądząc, że ujawniające się obecnie złe strony tej formy państwowej zniknęłyby wraz z upadkiem kapitalizmu. Z drugiej strony anarchiści i syndykaliści krytykują całą maszynerię parlamentarną i chcą innej metody regulowania spraw politycznych. Wszyscy oni jednak są demokratami w tym znaczeniu, że dążą do zniesienia wszelkich przywilejów i wszelkich sztucznych nierówności: wszyscy są obrońcami robotnika w współczesnym społeczeństwie” (1935: 22).
} 
Ostatecznie to nie instytucja własności prywatnej jest największą przeszkodą dla emancypacji jednostek, ale państwo, które kiedyś na niej wyrosło, a później stało się siłą samodzielną i pozostanie taką nawet po zniesieniu własności. Program emancypacji musi być zatem skierowany przeciw instytucji państwa, bez względu na to, czy jego gospodarka ma kapitalistyczny, czy socjalistyczny charakter.

\section{/// Kooperatywa, czyli prawdziwa alternatywa dla kapitalizmu}

Będzie to jednak bardzo szczególna walka z państwem, bez udziału przemocy, a nawet bez łamania prawa - państwo nawet nie będzie aktywnie bojkotowane, ale jedynie ignorowane. Ludzie świadomi charakteru tej organizacji nie będą korzystać z jej usług, ponieważ sami je sobie zorganizuja. Skoro państwo nie będzie spełniać żadnych funkcji, w naturalny sposób obumrze. Znikną nie tylko jego instytucje, ale nawet sama idea (por. Abramowski 1965: 62). Z całego programu marksistowskiego w to akurat Abramowski wierzy z całym przekonaniem. Wystarczy z życia społecznego usunąć te rzekome potrzeby ludzkie, które zaspokoić może jedynie państwo, a stanie się ono zbędne - właśnie tak, jak głosił to Tomas Paine sto lat wcześniej. Społeczeństwo potrafi bowiem zaspokoić własnymi siłami rzeczywiste potrzeby ludzkie. Nikomu nie uda się to indywidualnie, dlatego też ludzie łączą się z innymi. Łączą się właśnie poprzez rzeczy, które wspólnie wyprodukują, wprowadzą w obieg towarowy i wymienią na inne, niezależnie od kapitalistycznego rynku. Budowa społeczeństwa kooperatywnego postępować będzie zatem równolegle z budową kooperatywnej gospodarki, jednocześnie niekapitalistycznej i niesocjalistycznej (por. Abramowski 2009: 16), a przy tym efektywnej i stabilnej.

Zaszłaby więc - dowodzi Abramowski z utopijną wiara - zmiana ogromnej doniosłości w stosunkach ekonomicznych - celowe prowadzenie produkcji: zamiast wytwarzania chaotycznego, na oślep, jakie dzisiaj przeważa, produkcja musiałaby się stosować ściśle do rzeczywistych potrzeb ludności i oprzeć się na statystyce tych potrzeb. To, co dzisiaj już stanowi prawidło w związkach kooperatyw dla zakupów hurtowych, że wszystkie operacje handlowe i przemysłowe związków tych opierają się na dokładnym obliczeniu zapotrzebowań ze strony kooperatyw, to samo stosowałoby się wtedy do całego rynku i wytwórczości krajowej. Nie wytwarzano by zbytecznego nadmiaru, który powoduje często zastoje i kryzy- 
sy przemysłowe, mszczące się ciężko na ludności pracującej; nie wytwarzano by również rzeczy tandetnych, fałszowanych i niepotrzebnych, na które dzisiaj, przez reklamy i sztucznie stwarzaną modę, dają się naciagać masy publiczności, aby tylko fabrykanci i kupcy tych towarów zbytecznych i brzydkich mieli swoje zyski. Przy rynku kooperatywnym takie rzeczy będą niemożliwe, gdyż kooperatywy zamawiaja towary i badaja ich wartość. Produkcja spełniałaby wtedy swoje przyrodzone właściwe zadanie: zaspokajałaby istotne potrzeby ludzi. Zamiast służyć przedsiębiorstwom do gromadzenia zysków, służyłaby społeczeństwu, jego potrzebom i kulturze (tamże: 108).

Alternatywny ład nie narodzi się oczywiście z dnia na dzień, gdyż nie przyniesie go rewolucja polityczna ani polityka parlamentarna - to rosnąca samoorganizacja społeczeństwa spowoduje stopniowe obumieranie państwa. Nadejście kooperatyzmu będzie „ciche i spokojne”. Ruchowi zrzeszeniowemu przyświeca co prawda filozofia w szerokim rozumieniu pozytywistyczna - reformistyczna, nie rewolucyjna (por. Abramowski 1965: 276-277) - ale w istocie jest on żywiołowy: nie potrzebuje żadnej ideologii, nie musi więc wykazywać ideologicznej czystości i wikłać się w takie dogmatyczne spory jak nurt socjalistyczny. Kolejne zrzeszenia wyrastaja z samych potrzeb życiowych (por. tamże: 256), którym nie może sprostać kapitalistyczna organizacja społeczeństwa ${ }^{8}$.

Przekonując, że ruch kooperatywistyczny ma przed sobą przyszłość, Abramowski może już przywołać wiele przykładów udanych przedsięwzięć tego rodzaju z różnych stron Europy, choć raczej Zachodniej (por. 2009: 81-91). Szczególnie dobrze funkcjonuja kooperatywy na Wyspach Brytyjskich; wiele z nich może konkurować z typowymi przedsiębiorstwami kapitalistycznymi. Udane przykłady przedsięwzięć różnych kooperatyw pochodzą też z innych krajów europejskich, chociaż na kontynencie instytucje te domagają się nierzadko... zapomóg od państwa. Dodać trzeba,

\footnotetext{
7 Wiara w racjonalną alokację dóbr produkowanych przez niezależne od siebie kooperatywy jest wspólna zwolennikom spółdzielczości. Maria Dąbrowska, jej wielka entuzjastka, napisze nawet, że „dobrowolne zrzeszenia, oparte na rzeczywistej wspólności interesów, potrafią stosować planowość znacznie udatniej niż państwa z ich metodą przymusów i nakazów” (2014: 107).

${ }^{8}$ Dlatego też zdaniem Charles’a Gide’a można uznać, że celem ruch kooperatystycznego jest ostatecznie wywłaszczenie, „bo cóż mogliby uczynić kapitaliści ze swoimi fabrykami w dniu, w którym klasa robotnicza produkowałaby w swoich spółdzielniach wszystko, czego potrzebuje?” (1937: 143). Nie chodzi jednak o to, by pozbawić własności kapitalistów, ale by nadać własność robotnikom, a tym samym ich upodmiotowić; w kapitalizmie są tyleż użytkownikami narzędzi, co samymi narzędziami (por. tamże: 31 ).
} 
o czym już Abramowski nie pisze, że kooperatyzm rozwijał się również na ziemiach polskich, zwłaszcza w zaborze pruskim?. Sukcesy ruchu pozwalają mu napisać, że „[ś]wiat nie należy już wyłącznie do kapitalizmu. W demokratycznych krajach Zachodu tu i ówdzie tworza się jakby wyspy nowego ustroju społecznego" (2009: 105). Nowy ład gospodarczy nie jest utopią!

Samowystarczalność systemu gospodarczego opartego na kooperatywach wymaga według Abramowskiego czterech filarów: spółdzielni spożywców, kółka rolniczego, towarzystwa pożyczkowo-oszczędnościowego (lub wzajemnego kredytu) oraz związku robotniczego. Zadaniem pierwszej instytucji jest organizacja rynku, gromadzenie ludowego kapitału, a ostatecznie wspólna produkcja środków do życia. Zrzeszenie rolników przygotowuje ich do wyższej kultury uprawy ziemi możliwej dzięki większym wspólnym nakładom. Instytucje finansowe pozwalają zamienić małe, indywidualne oszczędności w wielkie kapitały - dzięki nim ludzie pracy mogą założyć własne przedsiębiorstwa. Związki zawodowe spełniają swą tradycyjną rolę - bronią robotników najemnych przed wyzyskiem, wpływając na podaż pracy i warunki zatrudnienia. Taka organizacja wspólnej pracy zapewnia nie tylko sprawiedliwy podział jej owoców, lecz także efektywność produkcji przewyższająca kapitalistyczną. Kapitalizm - tu Abramowski zgadza się z Marksem - jest bowiem ustrojem nie tylko niesprawiedliwym, ale też nieefektywnym - właśnie doszedł do granic swoich gospodarczych możliwości.

Efektywność gospodarcza kooperatyw jest zatem dla Abramowskiego równie ważna jak ich sprawiedliwy charakter. Spółdzielnie muszą przynosić zysk ${ }^{10}$. I uzyskaja go, ponieważ sklepy należące do kooperatywy będa sprzedawać po cenach rynkowych, a że będą miały zapewniony zbyt - ich współwłaściciele będą przecież kupować u siebie - wygrają z konkurencją handlu drobnomieszczańskiego, zwłaszcza jeśli zorganizują sobie tanie dostawy od spółdzielni producentów. Efektywność gospodarczą przynosi kooperatywie wyeliminowanie pośredników, czyli kupców (skądinąd często obcego pochodzenia, na co zwraca uwagę Abramowski). Cały zysk wytworzony przez kooperatywę jest własnością wspólną; część trafia do

\footnotetext{
${ }^{9}$ W momencie wybuchu I wojny światowej działało w zaborze pruskim 297 spółdzielni związkowych, do których należało prawie 150 tysięcy osób. W II RP istniało już 14 tysięcy spółdzielni zrzeszających ponad 3 miliony członków (por. Okraska 2014: 49, 68).

10 Abramowski wylicza zwięźle cztery zasady, którymi winna się kierować kooperatywa spożywcza: „1) sprzedawać towary za gotówkę; 2) sprzedawać po zwykłych cenach sklepowych, tj. drożej aniżeli sama kupuje; 3) kapitalizować dywidendę w udziałach i kasach wspólnych; 4) być stowarzyszeniem demokratycznym, tj. otwartym dla wszystkich i rządzącym się na zasadzie równości” (2009: 66).
} 
indywidualnych członków jako dywidenda (w kooperatywie spożywców będzie ona proporcjonalna do kwoty wydanej na zakupy w jej sklepach), a pozostała kwota - „fundusz gromadzki” - przeznaczona zostaje na ich utrzymanie i inwestycje. Członkowie kooperatywy sami zadecyduja, w jakich proporcjach, ale Abramowski ma nadzieję, że wraz ze wzrostem samoświadomości społecznej coraz większe kwoty będą pozostawać do wspólnego użytku (2009: 76).

Choć ład kooperatywny wymaga całego szeregu instytucji gospodarczych, rolę szczególnie istotną odgrywają w nim - według filozofa - spółdzielnie spożywców. To one mają największe możliwości rozwoju: nawet jeśli nie każdy jest producentem, każdy jest przecież konsumentem. Dzięki nim ludzie na skalę masową mogą stać się odpowiedzialnymi współwłaścicielami i promować w swoich przedsiębiorstwach nową kulturę pracy. Charles Gide, intelektualny patron tego nurtu spółdzielczości, do której należy Abramowski, pisze wręcz, że „[s]towarzyszenia spółdzielcze są odpowiednikiem w ustroju gospodarczym głosowania powszechnego w ustroju politycznym, ponieważ wszyscy sa spożywcami, tak samo jak każdy jest obywatelem" (1937: 194).

Mimo wielu podobieństw, także w strukturze własności, kooperatywy tym różnią się od kapitalistycznych spółek pracowniczych, że każdy z jej członków, bez względu na wielkość swojego udziału, ma taki sam wpływ na jej zarządzanie; obowiązuje w nich ściśle zasada, nawet bez względu na płeć: ,jeden człowiek - jeden głos” (Abramowski 2009: 65). Zebrania udziałowców mogą być więc szkołą demokratycznej samorządności - pełnej, bezpośredniej demokracji, jakiej nie znają obywatele żadnego państwa, nawet demokratycznego. Członkostwo w nich jest otwarte dla wszystkich i w pełni dobrowolne - nikt nie musi tu znosić arbitralnej woli innego człowieka. Poza tym obrastają one instytucjami, które sprzyjają wytworzeniu się tożsamości i lojalności grupowej - instytucjami wzajemnej pomocy, sądami polubownymi, kasami zapomogowymi, a także szkołami dla dzieci (por. tamże: 189-196). Można sądzić, że ich członkowie będą raczej reformować kooperatywy, niż je opuszczać, tym bardziej że oprócz równości i wolności pozwalają im one jeszcze doświadczyć odpowiedzialności za innych. To właśnie, przekonuje Abramowski, jest obecnie praktycznym doświadczeniem braterstwa (por. tamże: 167-169).

Kooperatywy zapewniają więc swoim członkom to, czego nie znaja oni jako obywatele - rzeczywisty wpływ na życie społeczne. Dają im zarówno udział we władzy, jak i kontrolę tejże władzy; nie tej scentralizowanej i odległej, która zawsze pozostanie narzędziem ucisku, ale tej, która ma 
największe znaczenie dla ich codziennego życia; w tych „nieterytorialnych rzeczpospolitych" urzeczywistniaja się prawa człowieka i obywatela (por. tamże: 23). One są też szkoła życia publicznego, bo nawet jeśli konsumpcja jest sprawą prywatna, wspólna produkcja środków do życia nabiera cech aktywności publicznej - człowiek uspołecznia się dzięki wspólnej pracy (por. tamże: 74). Będzie na tyle społeczny, na ile zechce; zaangażuje się tylko w te sprawy, które go rzeczywiście obchodzą. Abramowski słusznie powołuje się tu na Simmla, ponieważ to właśnie on spośród klasyków socjologii był szczególnie wrażliwy na aspektowy charakter uspołecznienia w zróżnicowanym społeczeństwie. Człowiek XX wieku żyje na przecięciu różnych kręgów społecznych, powinien mieć zatem prawo ich wyboru.

\section{/// Siła przyjaźni sąsiadów}

Ład spółdzielczy nie powstanie jednak bez wielkiej przemiany, jaka zajść musi w samym człowieku; ludzie ukształtowani przez kapitalizm traktować będą kooperatywy opacznie - tak jak specyficzne przedsiębiorstwa, których celem jest przynoszenie zysku akcjonariuszom. Bo też w istocie nie są one organizacjami charytatywnymi, ale gospodarczymi i muszą się kierować rachunkiem ekonomicznym; materialny zysk oznacza jednak zawsze wyzysk innych ludzi. Czysto wspólnotowy aspekt ludzkiej natury wykształcić musi się zatem w innego rodzaju społecznościach, które Abramowski nazywa „związkami przyjá́ni”.

Przyjaźń łącząca członków tych formalnych organizacji nie odpowiada dokładnie Arystotelesowskiej przyjaźni ze względu na korzyść, Abramowski nie mówi bowiem o wzajemnej korzyści, ale o wzajemnej pomocy. W pewnym sensie jest to przyjaźń ludzi etycznie dzielnych, skoro świadcza oni pomoc ze względu na potrzeby innych, ale też, inaczej niż Arystotelesowscy ludzie wielkoduszni, sami też potrzebują innych. Normą wymiany jest więc zasada do ut des - „daję, abyś i ty dał”. Dawanie jest tu nie mniej ważne niż otrzymywanie, ale też nikt nie daje z lękiem, że jemu samemu kiedyś zabraknie. Rzec można, że w związkach przyjaźni obowiązuje etyka wręcz wielkopańska, etyka szerokiego gestu, który może jednak liczyć na odwzajemnienie. W duchu Rousseau można to ująć tak, że w ładzie stowarzyszeniowym ,ja indywidualne” harmonijnie łączy się z ,ja społecznym”, ale się w nim bynajmniej nie rozmywa, skoro dobrowolne związki maja służyć niczemu innemu jak emancypacji jednostki ${ }^{11}$.

${ }^{11}$ Bartłomiej Błesznowski pisze o „przewrotnej doktrynie”, jaką jest „, fenomenalizm socjologiczny” Abramowskiego: łączy ona nie tylko indywidualizm ze wspólnota, ale też dowodzi ich wzajemnego 
Dlatego też Abramowski, piętnując małostkowy egoizm, jakim żywi się kapitalizm ${ }^{12}$, upatruje źródeł emancypacji bynajmniej nie w postawie ascezy, ale przeciwnie - w ,życiu pełnią życia”. Nowy porządek ma oswobodzić człowieka z więzów panującej etyki, rozszerzyć zakres ludzkich pożądań, uwolnić je spod władzy wąskiego materializmu; ma wyrwać duszę człowieka z „deptaka utylitaryzmu” (por. Abramowski 1965: 202). Kapitalizm przysposobił ludzi do sobkostwa, nauczył patrzeć na innych poprzez pożądane rzeczy. W związkach przyjaźni będzie inaczej; tu rzeczy będa jedynie pośredniczyć w relacjach między ludźmi. Bo jeśli kapitalizm wykorzystuje nawet wrodzone instynkty ludzkie, w związkach przyjaźni człowiek może rozwinąć inne, zgodne ze szczytnymi ideałami ludzkości. To w przyjaźni realizują się najpełniej równość i wolność; przyjaźń jest po prostu inną nazwą braterstwa. I to tyleż tego, które zadeklarowano jako rewolucyjną zasadę życia społecznego, co znanego od wieków braterstwa ewangelicznego, przez wieki zapomnianego (por. Abramowski 2009: 230). Abramowski pisze o tym podniosłym, wręcz egzaltowanym językiem:

W etyce braterstwa jest jeden tylko dogmat - bezwzględne poszanowanie człowieka, i jedna zasada pojmowania życia - jako interesu wspólności, w którym jednostka odnajduje i sens prawdziwy istnienia, i poszukiwane szczęście. Stąd wynika zupełne zrewolucjonizowanie pojęć i stosunków ludzkich; własności przeciwstawia komunizm - „wszystko dla wszystkich”; „obowiązkowi pracy w pocie czoła" - maksimum swobody jako warunek rozwoju i radości człowieka; państwu przeciwstawia się samorząd jednostki (1965: 197).

Powszechne braterstwo zastapi nie tylko wszechobecny w kapitalizmie egoizm, lecz także na swój sposób dopełniający go altruizm, zinstytucjonalizowany w organizacjach filantropijnych. Nie ma oczywiście między nimi równowagi; filantropia nie jest $\mathrm{w}$ stanie wyciągnąc $\mathrm{z}$ biedy ogromu mas ludzkich, jakie produkuje gospodarka oparta na chciwości. Abramowski nie demaskuje bynajmniej filantropii jako praktyki mającej uspokoić kapita-

uwarunkowania, ,autoreferencyjności świata społecznego w działaniu, a co więcej, w sumieniu jednostki" (Błesznowski 2014: 28).

${ }_{12}$ Abramowski zapewne zgodziłby się też z Karlem Polanyim, że kapitalizm walnie ten instynkt rozwinął, podobnie jak z jego poglądem, że „[h]istoria gospodarcza dowodzi, że narodziny rynków krajowych w żadnym wypadku nie były skutkiem stopniowego i spontanicznego uwolnienia sfery gospodarczej od kontroli państwa. Przeciwnie, ukonstytuowanie się rynku wynikało ze świadomej i często gwałtownej interwencji ze strony państwa, które narzucało społeczeństwu organizację rynkową w celach pozaekonomicznych" (Polanyi 2010: 296). 
listyczne sumienie; jest ona po prostu reaktywna, nie może też rozwinać się na skalę przeciwdziałająca patologiom, ponieważ wymaga postawy przeciwnej do tej, do której przysposabia ludzi cały system. Czyż tego samego nie można jednak powiedzieć o braterstwie związków przyjaźni? Czy mogą utrzymać się enklawy ducha wspólnotowego w morzu powszechnego egoizmu? Abramowski jest tego świadom; w istocie, związki przyjaźni rozwiną się na skalę masową dopiero w gospodarce kooperatywnej, do której powstania same powinny się przyłożyć, zakładając własne spółdzielnie.

Same związki przyjaźni, inaczej niż kooperatywy, nie powstaja jednak dla osiagnnięcia wspólnych korzyści, ale aby realizować indywidualne potrzeby. W kapitalizmie na wszystkie potrzeby - ale tylko tych, którzy maja na to środki - odpowiada anonimowy rynek, w ładzie stowarzyszeniowym odpowie na nie konkretny człowiek - przyjaciel $^{13}$. Pieniądz jako medium między ludźmi z ich potrzebami zastapi pomoc wzajemna ${ }^{14}$. Członkowie związków mogą na nią liczyć nie dlatego, że jej wyświadczenie leży w czyimkolwiek interesie, ale $z$ tego względu, że należy się ona osobie w potrzebie. Związki będa więc przyznawać zapomogi pieniężne i w naturze, będą pomagać w poszukiwaniu pracy, służyć pomocą w opiece nad dziećmi, ludźmi chorymi i starszymi, świadczyć pomoc prawną, polubownie załatwiać spory, wreszcie krzewić oświatę poprzez dystrybucję darmowych książek. Trudno nawet wyliczyć wszystkie zadania związków, bo właściwie w żadnej dziedzinie życia człowiek nie może się obejść bez pomocy drugiego.

Inaczej niż spółdzielnie, związki są organizacjami terytorialnymi, sąsiedzkimi. Powinny skupiać ludzi, którzy znają się bezpośrednio; będzie to pewnie nie więcej niż 1000 osób (por. Abramowski 2009: 226). Abramowski przyrównuje je nawet do wielkich rodzin; na wsi bliskość zamieszkania nakładałaby się nawet na więzi rodzinne, w mieście już niekoniecznie. Nie

\footnotetext{
${ }^{13}$ Alexis de Tocqueville tymczasem przekonuje, że choć dobroczynność publiczna wydaje się piękniejsza i bardziej skuteczna niż prywatna, to jednak tylko ta, będąc cnota indywidualną, jest społecznie wartościowa: „Biedak, który prosi o jałmużnę w imię prawa, znajduje się w położeniu jeszcze bardziej upokarzającym niż ubogi, który odwołuje się do współczucia swoich bliźnich w imię Tego, który jednakim wzrokiem spogląda na biedaka i bogacza i poddaje ich równym prawom. [...] Ale to jeszcze nie wszystko: indywidualna jałmużna buduje cenną więź pomiędzy bogatym i biednym. Pierwszy z nich, przez sam fakt świadczenia pomocy, okazuje zainteresowanie losem tego, którego nędzy postanowił ulżyć; drugi, otrzymawszy wsparcie, którego nie miał prawa wymagać i którego może nie spodziewał się uzyskać, jest skłonny do wdzięczności” (2009: 56-57). ${ }^{14}$ Karl Mannheim dowodzi czegoś wręcz odwrotnego: opieka społeczna, choć nie pozbawiona elementu współczucia, w czasach współczesnych nie może opierać się już na nim. „Pomoc społeczna przybrała formy instytucjonalne, ponieważ człowiek współczesny pragnie mieć jasno określone prawa i obowiązki i raczej nie chce korzystać z osobistych względów. [...] Rozwój biurokracji zrodził więc nieznaną dotychczas potrzebę - chcemy, aby wiele naszych spraw osobistych było traktowanych bezosobowo" (1974: 476).
} 
ma to wielkiego znaczenia; istotne jest tylko to, by związek zakładali ludzie dzielący w jakiejś mierze swoje codzienne życie - mieszkańcy jednej wioski, dzielnicy, a może nawet dużej kamienicy. Ta bezpośrednia bliskość ważna jest oczywiście dlatego, że tworzy zobowiązania moralne, których nie trzeba egzekwować instytucjonalnie - biurokracja w związku ma być ograniczona do minimum. Potrzebny będzie oczywiście wspólny fundusz (z rocznych czy miesięcznych składek) na potrzeby doraźnej pomocy oraz wspólnie wybrany sąd rozjemczy do polubownego rozstrzygania sporów. Wszystkie problemy dnia codziennego powinny być rozwiązywane na miejscu, bez angażowania struktur związku wyższego szczebla, nie mówiąc już o instytucjach państwa.

Ponieważ związki przyjaciół nie sa jednak organizacjami samowystarczalnymi, muszą korzystać z zysków wypracowanych w założonych przez siebie kooperatywach. One też będą zaopatrywać członków związków w środki do życia, udzielać im kredytu i zapomóg, kształcić ich dzieci itp. Na poziomie lokalnym związki przyjaźni realizowałyby więc realną politykę gospodarczą nakierowaną na zysk, a dopiero w drugiej kolejności na realizację potrzeb. Rzec można, że kooperatywy i związki przyjaźni łączą to, co Adam Smith rozdzielał: sympatię i interes, dowodząc, że kierując się rozsądkiem, będziemy maksymalizować swoja korzyść własną. Żyjąc w utopii Abramowskiego, pójdziemy po mięso do naszego rzeźnika, bo zakupy u niego podnoszą naszą dywidendę, ale też z sympatii, bo jest naszym towarzyszem w związku, nie chcemy więc, by popadł w biedę $z$ braku klientów.

Związki przyjánini będą wyrastać spontanicznie, ale nie powinny podlegać żywiołowi uczuć. Ich organizacja jest niezbędna, skoro swym zasięgiem objąc mają cały kraj. Trzeba jednak zachęcić ludzi do ich zakładania, wskazując na przyszłe korzyści; to zadanie Centralnej Rady Związków Przyjaźni, która też stać będzie na straży „czystości zasad i kierunku” związków. Choć bowiem prawo przynależności do związku przysługuje każdemu, zgromadzenie może usunąć tych jego członków, którzy złamia złożone przyrzeczenie. Wszyscy są tu równie kompetentni do wydania wyroku, ponieważ rota tegoż przyrzeczenia ma charakter zobowiązania moralnego, a nie prawnego. Brzmi ona tak:

Ja X.Y. przyrzekam wobec Boga i sumienia własnego, że od tej chwili będę wystrzegał się w życiu swoim samolubstwa, że nie będę nigdy krzywdził innych ludzi dla swego interesu, że przeciwnie starać się będę w miarę możności pomagać innym i sto- 
sować w życiu swoim idee pomocy wzajemnej i odnosić się do innych ludzi jak do przyjaciół, których bieda i krzywda nie moga być dla mnie obojętne. W stosunku do Związku Przyjaźni, do którego wstępuję, przyrzekam zupełną szczerość w postępowaniu, jak również wystąpienie ze Związku, gdyby moje życie nie zgadzało się z głównymi zasadami związku pomocy wzajemnej i przyjaźni ludzkiej (Abramowski 2009: 239-240).

\section{/// Rzeczpospolita przyjaciół}

Związki przyjaźni wraz z kooperatywami spełniać będą ostatecznie wszystkie funkcje współczesnego państwa; jedyne, do czego nie są zdolne, to obrona granic. I to też jest jedyną racją przemawiającą za pozostawieniem państwa w szczątkowej postaci. Być może tylko tymczasowo; dlaczegóż bowiem etyka braterstwa nie miałaby objać swoim zasięgiem całego świata, całego rodu ludzkiego? (por. Abramowski 1965: 198). Plan Abramowskiego nie sięga jednak tak daleko; związki przyjaźni i kooperatywy maja doprowadzić ostatecznie do niepodległej Polski, do wyzwolenia kraju spod obcej władzy.

Utopia Abramowskiego jest Polska wyzwolona z niewoli politycznej i ekonomicznej, z władzy ludzi i rzeczy. Jest Rzeczpospolitą Przyjaciół, wspólnie produkujących środki do życia i świadczących sobie wzajemna pomoc. Przyjaźn ta jest rzeczywiście odczuwana, bo zamyka się w granicach świata życia codziennego, daje świadectwo czynem, nie słowem. Jest też jedyną więzią społeczną między ludźmi. Więź symboliczna nie ma bowiem namacalnego sensu, a każda inna realna byłaby wymuszona. Przyjaciół człowiek wybiera z własnej woli; popycha go do tego jedynie naturalna potrzeba.

Życiowa etyka przyjaźni dąży do najwyższego spotęgowania sił każdego człowieka przez wyzwolenie go z tego, co w życiu dzisiejszym najbardziej pomniejsza jego siły - jak nędza, wyzysk, osamotnienie, bezradność, samolubstwo i jak odpowiedniki psychiczne tych warunków życia - również pomniejszające siły - zgnębienie, smutek, nienawiść, rozgoryczenie, beznadziejność. W takich warunkach człowiek skazany jest na ciagłe upokorzenie, na korzystanie z jałmużny, zmuszony jest do kłamania i poniżania się wobec innych (Abramowski 1980: 596). 
Przed tym wszystkich ratują człowieka przyjaciele. Na nic innego, a zwłaszcza na państwo, nie może liczyć. W utopii Abramowskiego przyjaźń nie dopełnia sprawiedliwości, ale ją zastępuje i rekompensuje jej zasadniczy feler - ślepotę na potrzebującego człowieka.

Idea wyzwolenia Polski i jej odbudowa w nowej formie ma przy tym aspekt mesjanistyczny: dzięki związkom Polacy odrodzą się moralnie, bo dziś nie tylko materialnie zależą od zaborców, są także ich duchowymi niewolnikami (por. Abramowski 1965: 237). Stuletnia niewola sprawiła, że stracili wszelką inicjatywę, „potrzebują bata”, by zrobić cokolwiek razem. Boją się być Polakami, a dla indywidualnej korzyści gotowi są też wyrzec się ojczyzny. Polska nie odzyska więc niepodległości w drodze zbrojnego powstania ani w rezultacie wielkiej wojny między zaborcami; może być niepodległa jedynie jako braterska wspólnota ludzi wolnych i równych. Rzec można, że albo przyszła Polska będzie solidarna, albo nie będzie jej wcale.

Mutatis mutandis to samo moga powiedzieć o współczesnym kapitalizmie jego krytycy spod znaku utopii nazwanej przeze mnie ,akapitalistyczną"; nie można relacji między ludźmi sprowadzać za pośrednictwem rzeczy do wymiany towarowej! Ich rzecznikiem mógłby być Marcel Mauss, który kilka lat przed Wielkim Kryzysem 1929 roku pisał:

Przede wszystkim powracamy - i trzeba powrócić - do obyczaju „wydatków szlachetnych”. Trzeba, by, jak w krajach anglosaskich, jak w tylu innych społeczeństwach współczesnych, dzikich i wysoko cywilizowanych, bogaci zaczęli ponownie - dobrowolnie, lecz również przymusowo - uważać się niejako za skarbników swych współobywateli. Cywilizacje starożytne, z których wywodzą się nasze, znały jubileusze, liturgie, choregie, trierarchie, syssycje (wspólne posiłki), obowiązkowe wydatki edyla i konsulów. Trzeba powrócić do praw tego rodzaju (1973: 308-309).

Mauss odnotowuje przy tym z aprobatą politykę władz, którą dziś uznalibyśmy za pierwociny państwa bezpieczeństwa socjalnego. Współcześni przedstawiciele utopii „obokkapitalistycznej” - entuzjaści ekonomii współdzielenia - bliżsi sa jednak Arystotelesowi i buduja swoje sieci wymiany niezależnie od instytucji państwowych. 
Bibliografia:

/// Abramowski E. 1965. Filozofia spoteczna. Wybór pism, Państwowe Wydawnictwo Naukowe.

/// Abramowski E. 1980. Metafizyka doświadcralna, Państwowe Wydawnictwo Naukowe.

/// Abramowski E. 1986. Rzeczpospolita prayjaciót. Wybórpism społecznych ipolitycznych, Instytut Wydawniczy Pax.

/// Abramowski E. 2009. Braterstwo, solidarność, współdriałanie, Stowarzyszenie „Obywatele Obywatelom”.

/// Błesznowski B. 2014. Utopia w stużbie demokracji-wokót z̧ródeł kooperatyzmu, [w:] Kooperatyż, spótdzielczość, demokracja. Wybórpism, red. B. Błesznowski, Wydawnictwa Uniwersytetu Warszawskiego, s. 7-45.

/// Dąbrowska M. 2014. Rece w uścisku, [w:] Kooperatyzm, spótdzielczość, demokracja. Wybór pism, red. B. Błesznowski, Wydawnictwa Uniwersytetu Warszawskiego, s. 103-110.

/// Gide Ch. 1937. Kooperatyzm, tłum. S. Thugutt, „Społem” Związek Spółdzielni Spożywców [publikacja zamieszczona na stronie internetowej Podlaskiej Biblioteki Cyfrowej].

/// Mannheim K. 1974. Człowiek $i$ społeczeñstwo w dobie przebudowy, tłum. A. Rażniewski, Państwowe Wydawnictwo Naukowe.

/// Mauss M. 1973. Szkic o darze, tłum. K. Pomian, [w:] tegoż, Antropologia i socjologia, Państwowe Wydawnictwo Naukowe.

/// Okraska R. 2014. Od samopomocy do wizji nowego ustroju. Zarys dziejón rozwoju materialnego i ideowego spótdzielczości w Polsce do 1939 roku, [w:] Kooperatyzm, spótdrielczość, demokracja. Wybór pism, red. B. Błesznowski, Wydawnictwa Uniwersytetu Warszawskiego, s. 46-71.

/// Polanyi K. 2010. Wielka transformacja. Polityczne i ekonomiczne źródta naszych crasón, tłum. M. Zawadzka-Strączek, Wydawnictwo Naukowe PWN.

/// Russell B. 1935. Drogi do wolności. Socjalizm, anarchizm i syndykalizm, tłum. A. Kurlandzka, Towarzystwo Wydawnicze „Rój”.

/// Tocqueville de A. 2009. Raport o panperyzmie, tłum. W. Turopolski, J. Strzelecka, Wydawnictwa Uniwersytetu Warszawskiego. 
/// Waśkiewicz A. 2017. Przyjażń dla korzyści, ale też z korzyścia dla spoteczeństwa, „Przegląd Filozoficzno-Literacki”, nr 3-4 (48), s. 413-425.

/// Waśkiewicz A. 2020. Ludzie-rzeczy-ludzie. Rzeczo utopiach, w których rzeczy tacza, a nie driela, Universitas [w druku].

/// Żuk P., red. 2008. Spotkania z utopia w XXI wieku, Oficyna Naukowa.

\section{/// Abstrakt}

Artykuł przedstawia wizję ładu stowarzyszeniowego Edwarda Abramowskiego, na który składają się gospodarcze kooperatywy oraz samopomocowe związki przyjaźni. Ład stworzony oddolnie ma być odpowiedzią na permanentny nieład tworzony przez kapitalizm i przymus wywierany przez państwo. Kooperatywy kierują się z konieczności logiką zysku ekonomicznego, ale dzielonego równo wśród swych członków, związki przyjaźni zaś empatią, mogąca jednak liczyć na odwzajemnienie. Dobrowolne stowarzyszenia zdolne są wypełnić niemal wszystkie funkcje niezbędne do funkcjonowania społeczeństwa, mogą więc zastąpić państwo, także państwo socjalistyczne, w które wpisana jest instytucja - choćby demokratycznego - przymusu. Pozostająca pod zaborami Polska może się odrodzić właśnie w tej formie, mimo pozostania, nawet formalnie, pod zwierzchnością rosyjskiego cara. Autor wpisuje wizję odrodzonej Rzeczypospolitej Abramowskiego w nurt utopii „akapitalistycznej”, wywodzący się z Arystotelesowskiej koncepcji przyjaźni ze względu na korzyść. W postaci ekonomii współdzielenia nurt ten pojawił się ponownie po kryzysie ekonomicznym 2008 roku.

Słowa kluczowe:

Abramowski, kooperatywa, przyjaźń, utopia, anarcho-syndykalizm

\section{/// Abstract}

The Goodwill of the Butcher: Edward Abramowski's Vision of an Order Based on Associations

This article presents Edward Abramowski's vision of an order based on associations such as cooperative businesses and self-help friendship unions. Abramowski imagined the new, grassroots-derived order to be the answer 
to the permanent disorder produced by capitalism and state coercion. Cooperatives are necessarily guided by the aim of economic profit, but that profit is divided equally among the cooperative members; friendship unions are guided by empathy and rely on reciprocity. Voluntary associations can provide nearly everything society needs in order to function. They can thus replace the state, including the socialist state, in which the institution of coercion - even if democratic - is inscribed. Abramowski thought that partitioned Poland could be reborn in this form, even while the nation remained formally under the sovereignty of the Russian tsar. The author of the article describes Abramowski's vision of a reborn Republic as part of the current of "a-capitalist" utopias which derive from the Aristotlian concept of utility-based friendship. In the form of the sharing economy this current reappeared after the economic crisis of 2008.

Keywords:

Abramowski, cooperative, friendship, utopia, anarcho-syndicalism

/// Andrzej Waśkiewicz - profesor Uniwersytetu Warszawskiego, pracownik Instytutu Socjologii i wykładowca w Kolegium Artes Liberales UW. Jest autorem kilku monografii z zakresu historii idei; ostatnia z nich to The Idea of Political Representation and Its Paradoxes (Peter Lang 2019, wyd. polskie Scholar 2012). W 2020 roku nakładem wydawnictwa Universitas ukaże się jego książka Ludziie-rzeczy-ludzie. Rzecz o utopiach, w których rzeczy tacza, a nie dziela.

ORCID: https://orcid.org/0000-0002-2192-0418

E-mail: waskiewa@is.uw.edu.pl 